\title{
FREQUENCY OF HCV AND MEAN AGE
}

\author{
DR. S. MEHTABULLAH KAKAKHEL, MBBS, FCPS \\ Registrar \\ Department of Medicine, Medical B ward, \\ Khyber teaching hospital, Peshawar. \\ Dr. Mohammad Haroon, MBBS \\ Post Graduate Trainee \\ Department of Medicine, Medical B, \\ Khyber teaching hospital, Peshawar.
}

\author{
DR. MOHAMMAD TARIQ, MBBS, MCPS \\ Post Graduate Trainee \\ Department of Medicine, Medical B ward, \\ Khyber teaching hospital, Peshawar.
}

\begin{abstract}
DR. SADEEQ-UR-REHMAN, MRCP
Professor, Department of Medicine, Medical B ward, Khyber teaching hospital, Peshawar.
\end{abstract}

Article Citation:

Kakakhel SM, Tariq M, Haroon M., Sadeeq-ur-Rehman, Cirrhosis; Frequency of HCV and mean age. Professional Med J Sep 2010; 17(3):449454

\begin{abstract}
Objectives: To know the frequency of HCV in patients with cirrhosis and to know the mean age of patients with cirrhosis. Design: A descriptive study. Setting: Medical Unit Khyber Teaching Hospital Peshawar Period: From Jan 2007 to Jan 2008. Materials \& Methods: 100 consecutive cirrhotic patients or those with signs and symptoms of cirrhosis, admitted to the medical units. They were either known cirrhotic or having signs and symptoms of chronic liver disease and diagnosed as cirrhotic during their stay in the hospital on the basis of ultrasound findings. The routine investigations including liver function test (LFTs), prothrombin time (PT), activated partial thromboplastin time (APTT), serum albumin were carried out in all patients. Ultrasound was the main tool for the diagnosis of cirrhosis liver. The hepatitis C virus (HCV) status was diagnosed by detecting Anti HCV Antibodies by enzyme linked immunosorbent assay (ELISA). Polymerase chain reaction (PCR) for HCV RNA was done only in affording patients. Results: The overall frequency of HCV was 52 in 100 patients. Out of these 52 HCV positive patients, PCR for HCV RNA was positive in 20 patients (38.15\%) and the rest of the patients were not able to afford the test. Out of 52 HCV positive patients the number of male were more (1.8:1) as compared to female. The age of the patients ranged from 45-65 years, the majority being from 45 to 65 years with the mean age of 52 years. The stratification of risk factors was not the objective of this study. However, a note was made of exposure to various risk factors. Most of the patients had the history of receiving injections in the past from quacks. Conclusion: It is concluded that chronic HCV infection is the commonest cause of cirrhosis leading to chronic ill health, great economic burden on family and health care system and mortality. As there is no treatment for cirrhosis so prevention, early detection of HCV infection and prompt treatment of HCV infected patients will undoubtedly lead to a decrease in morbidity and mortality from this silent epidemic.
\end{abstract}

Key words: Hepatitis C virus, frequency, cirrhosis.

\section{INTRODUCTION}

Cirrhosis of the liver is pathologically defined with a spectrum of characteristic clinical features. Pathologically cirrhosis is characteristized by parenchymal necrosis, regeneration and scarring ${ }^{1}$. The clinical features of cirrhosis derive from the morphological alterations and often reflect the severity of the disease. Loss of hepatocellular mass leads to the jaundice, edema, coagulopathy and other metabolic abnormalities while distorted vasculature leads to portal hypertension and its sequelae that is GI varices and splenomegaly ${ }^{2}$.

Cirrhosis is a common disease and is responsible for $10 \%$ of hospital admission and over $30 \%$ of chronic illnesses in our area ${ }^{3}$. Cirrhosis liver is now the chief reason for liver transplantation ${ }^{4,5}$. The commonest cause of cirrhosis liver is alcohol consumption in USA and Europe while Hepatitis B Virus and Hepatitis C Virus is responsible for $75 \%$ of cirrhosis liver in Asian countries ${ }^{6}$.

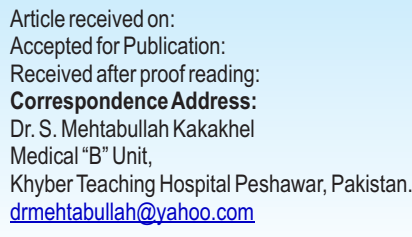

29/09/2009

$01 / 04 / 2010$

$07 / 08 / 2010$ 
Hepatitis C Virus is an RNA virus, discovered in $1988^{7,8}$. It can be detected in the serum by antibodies to the HCV or by PCR which detects HCV RNA ${ }^{9}$.

Risk factors for transmission are unscreened blood transfusions, per cutaneous route like injections, ear or nose piercing, tattoing, accidental pricks in medical personals, procedures like endoscopies, surgery and circumcission. Sharing of nail clippers, razors and tooth brushes are other risk factors ${ }^{10}$. While the perinatal and sexual transmission is $5 \%{ }^{11}$.

Recognition of potential risk factors, changes in the pattern of using intravenous drugs, and improved blood supply have led to the dramatic fall in the incidence of acute infection in recent years. But the overall prevalence of chronic infection has not fallen due to persistence of infection after previous acute infection with HCV. 170 million people that is $3 \%$ of the population is infected with $\mathrm{HCV}^{12}$ while in Pakistan the prevalence is $3-7 \%{ }^{13}$.

After acute infection with $\mathrm{HCV}$, there is $80 \%$ chance of chronic infection, $20 \%$.of these patients will develop cirrhosis in the next 10 years. The progression also depends upon the age of acquision, level of vireamia, duration of infection, other hepatitis viral infection and use of alcohol ${ }^{14}$. Patients having no history of acute infection that is incidentally found, their natural history is still to be determined ${ }^{15}$.

Among patients with compensated cirrhosis, 10 year survival is $80 \%$, mortality occurs at a rate of $2-6 \%$ per year, decompensation at a rate of $4-5 \%$ per year and hepatocellular carcinoma at a rate of $1-3 \%$ per year ${ }^{16}$.

\section{PATIENTS AND METHODS}

We conducted a descriptive, cross sectional, one center (Medicine Department, Khyber Teaching Hospital, Peshawar) study of 100 consecutive cirhotic patients or those with signs and symptoms of cirrhosis, admitted to the medical units from January 2007 to January 2008. All consenting patients of more than 15 years of age and patients with cirrhosis: a) those who were previously diagnosed as cirrhosis on ultrasound, b) those having signs and symptoms of chronic liver disease and ultimately diagnosed as cirrhosis on ultrasound were included in the study. Those patients with signs and symptoms of chronic liver disease but no evidence of cirrhosis on ultrasound and those cirrhotics who are known or turn out to be HBsAg were excluded from the study.

All patients, fulfilling the above inclusion criteria were admitted to the medical units. A detailed history, thorough general physical and systemic examination was done. Using a proforma, demographic characteristics of all the patients were recorded. If previously known cirrhotic, duration since diagnosis and history of HCV positivity was noted. Patients were labelled as having chronic liver disease by illustration of signs and symptoms of chronic liver disease like jaundice, ascites, hepatic encephalopathy, hematemesis/ melena, splenomegaly, clubbing, palmar erythema or spider naevi. Inquiry was made about exposure to risk factors like injection, history of surgery, ear/ nose piercing, blood transfusion, addiction and extramarital sex. These patients were diagnosed as cirrhosis on the basis of ultrasound examination. In all patients fulfilling the above mentioned criteria, HCV was diagnosed by detecting of HCV antibodies on $3^{\text {rd }}$ generation ELISA. The affording patients were confirmed by detecting the HCV RNA by PCR.

As this was a descriptive study, no specific statistical test was required. Mean, median, mode, percentage and ratios were recorded for different variables using SPSS version 11.0 .

\section{RESULTS}

This study was conducted in the Medicine Department of Khyber Teaching Hospital, Peshawar, hundred patients with cirrhosis or signs and symptoms of cirrhosis were admitted from the Out Patient Department and were analyzed for different parameters. The main parameter of the study such as age, sex, frequency of Anti HCV and PCR for HCV RNA, etc were analyzed to see their Inter relationship and significance. 
Out of these 100 patients, $52(52 \% 0$ patients turned out to be Anti HCV positive. Therefore the frequency of HCV in cirrhotic patients at Khyber Teaching Hospital, Peshawar is $52 \%$, as shown in the figure No 1 .

Fig-1. Frequency of HCV in 100 patients with cirrhosis

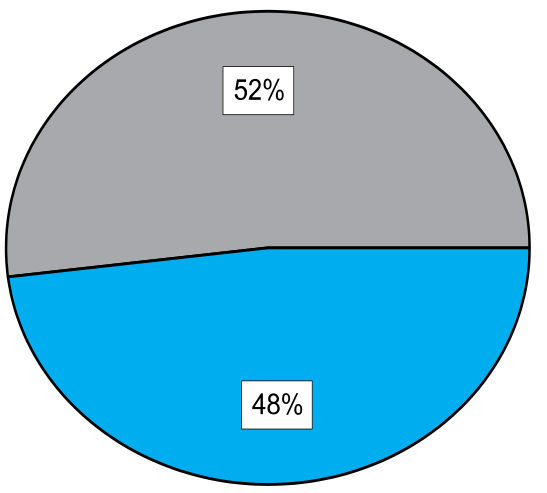

HCV Positive Cirrhosis

HCV Negative Cirrhosis

Of the 52 Anti HCV positive patients, 18(34.61\%) were female and $34(65.38 \%)$ were male, as shown in the Figure 2.

Majority of the patients were in the age range of $45-65$ years. As shown in the table I.

The mean age was 52 years.

The number of patients previously diagnosed as cirrhosis were 54 , being diagnosed on ultrasound. The rest of the patients were having signs and symptoms of chronic liver disease and were evaluated during ward stay, ultimately diagnosed as cirrhosis on ultrasound studies.

The presenting features were ascites, hepatic encephalopathy, hematemesis. The detail is given in the table ll.

Out of 52 anti HCV antibodies positive patients only 20 could be offered qualitative PCR for HCV RNA. The rest could not afford due to financial limitations.
Fig-2. Male to female ration in $52 \mathrm{HCV}$ positive cirrhosis patients

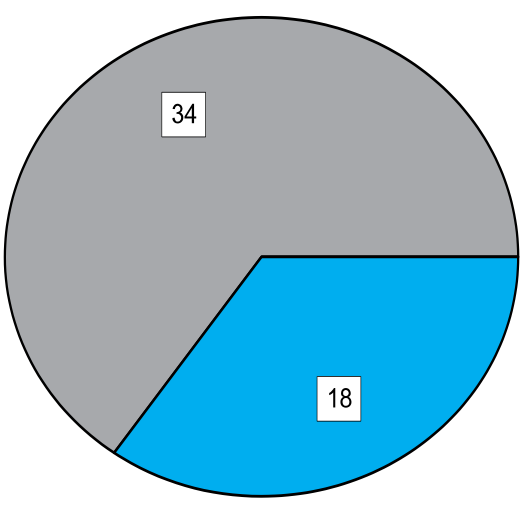

Female

Table-I. Age wise distribution of 100 patients with cirrhosis

\begin{tabular}{|l|c|c|}
\hline Age & No. of pts & \%age \\
\hline $45-50$ & 15 & $15 \%$ \\
\hline $51-55$ & 40 & $40 \%$ \\
\hline $56-60$ & 35 & $35 \%$ \\
\hline $61-65$ & 10 & $10 \%$ \\
\hline
\end{tabular}

\begin{tabular}{|l|c|c|}
\hline \multicolumn{3}{|c|}{ Table-ll clinical presentation of patients. } \\
\hline Symptoms & No. of pts & $\%$ ge \\
\hline Ascites & 80 & $80 \%$ \\
\hline Hepatic encephalopathy & 55 & $55 \%$ \\
\hline Hematemesis/melena & 35 & $35 \%$ \\
\hline Jaundice & 65 & $65 \%$ \\
\hline Splenomegaly & 78 & $78 \%$ \\
\hline Palmar erythema & 45 & $45 \%$ \\
\hline Clubbing & 20 & $20 \%$ \\
\hline Caput medusae & 30 & $30 \%$ \\
\hline Spider naevi & 15 & $15 \%$ \\
\hline Dupuytren's contracture & 05 & $05 \%$ \\
\hline
\end{tabular}


Only one case of Hepatocellular carcinoma was detected in these 100 patients.

The stratification of various risk factors was not the objective of this study, primarily. However a note was made of exposure to various risk factors. Majority of the patients gave the history of injections in the past $(90$ patients). These are shown in the table III. Ultrasound was the main tool for the diagnosis. On ultrasonography 96 patients had chronic parenchymal liver disease and or signs of cirrhosis with portal hypertension like splenomegaly and ascites. In one patient Hepatocellular carcinoma was diagnosed on ultrasound. Out of these 100 patients, 60 were male and 40 were females.

\begin{tabular}{|l|c|l|}
\hline \multicolumn{3}{|c|}{$\begin{array}{c}\text { Table-III. Frequency of various suspected risk factors in } \\
\text { patients with cirrhosis }\end{array}$} \\
\hline Risk factor & No. of pts & $\%$ age \\
\hline Infection & 90 & $40.72 \%$ \\
\hline History of jaundice & 55 & $24.89 \%$ \\
\hline History of surgery & 25 & $11.31 \%$ \\
\hline Ear/nose piercing & 15 & $6.79 \%$ \\
\hline History of blood transfusion & 20 & $9.04 \%$ \\
\hline History of sharing razor & 10 & $4.53 \%$ \\
\hline Addiction & 05 & $2.26 \%$ \\
\hline Extra marital sexual relation & 01 & $0.46 \%$ \\
\hline
\end{tabular}

\section{DISCUSSION}

Cirrhosis of the liver is a very common disease in our country. It is responsible for $10 \%$ of hospital admission and $30 \%$ of chronic illnesses in our area ${ }^{2}$. There are many causes of the cirrhosis but the commonest cause is chronic infection with HCV. $3 \%$ of the world population is infected with $\mathrm{HCV}^{7}$. Chronic HCV infection leading to cirrhosis is becoming a great health problem even in developed nations but because of the lack of proper health care it is becoming an epidemic in third world countries like Pakistan.

The presence of other risk factors like other hepatitis viral infection, alcohol use, fatty liver, level of viraemia, age of acquisition and duration of infection also predict the progression of HCV infection to end stage liver disease ${ }^{17}$.

In our series of 100 cirrhotic patients, most of them were in the range $(40 \%)$ of $45-65$ years, followed by $(35 \%)$ in the range of 56-60 years. Our data correlates well with the report of Nadeem MA et al who reported the age range of 51-60 years ${ }^{18}$. While Khurram $M$ et al reported the age range of $54.1 \pm 13.8$ years ${ }^{19}$ Umar $\mathrm{M}$ et al stated age range of $53.76 \pm 8.52$ years $^{20}$. The report of Chohan $R$ et al state that the age range is $44.56 \pm 7.23$ years ${ }^{21}$.

In this study the frequency of HCV in cirrhotic patients was $52 \%$. It correlate well with the Nadeem MA et al whose data showed figure of $55 \%$ for the positivity of Anti HCV antibodies ${ }^{18}$. Shaikh MA et al reproduced a figure of $51 \%$ of HCV positivity in patients with chronic liver disease ${ }^{6}$. Faroogi $\mathrm{Jl}$ found HCV frequency of $59 \%$ in his study $^{22}$. Other studies showed different frequencies of $\mathrm{HCV}$ in Cirrhosis, like Khokhar $\mathrm{N}$ et $\mathrm{al}^{23}$ gave HCV frequency as $70 \%$, while lqbal S et al states it to be $41 \%{ }^{3}$. Similarly in Khan AA Study the frequency is $68 \%{ }^{24}$. Sultana N et al stated that HCV is responsible in $29.63 \%$ patients with chronic liver disease ${ }^{25}$. This differences may be due to the size of the sample, the demographic variations, sampling technique and diagnostic methods used.

There is strong association of hepatocellular carcinoma and HCV related cirrhosis ${ }^{5,26}$ and in this study one patient turned out to have hepatocellular carcinoma.

More males are affected than the females that is $1.88: 1$ which correlates with the study of lqbal $S$ who stated the male to female ratio of $2: 1^{3}$. This may be due to the facts that lesser number of females attend the hospital and are also comparatively less exposed to the risk factors.

The limitation of this study was the inability to carry out PCR for HCV RNA in all anti HCV positive patients due to financial constraints. Therefore PCR was performed only in 20 affording patients out of 52 anti HCV positive patients. 
Currently the best curative hope for the HCV related is liver transplantation which has revolutionized outlook in USA but regrettably it is not yet available in our setting, only palliative treatment is given for advanced disease.

Screening is mandatory for early detection and prompt treatment but it requires a lot of expenditure which has significant impact on health care system. In conclusion the early diagnosis of HCV and its treatment before the cirrhosis, will improve the out look in future. This study correlates well with the available data.

\begin{tabular}{|c|c|c|}
\hline Authors & Year of Publication & \%age \\
\hline Nadeem MA et al18 & 2002 & $55 \%$ \\
\hline Sheikh MA et al6 & 2003 & $51 \%$ \\
\hline Farooq Jl et al 22 & 2002 & $59 \%$ \\
\hline Khokhar $\mathrm{N}$ et al 23 & 2003 & $70 \%$ \\
\hline Iqbal S et al3 & 2002 & $41 \%$ \\
\hline Khan $A$ et al 24 & 2002 & $68 \%$ \\
\hline Sultana et al 25 & 1999 & $29.6 \%$ \\
\hline Other study & 2006 & $52 \%$ \\
\hline
\end{tabular}

\section{CONCLUSIONS}

It is concluded that HCV is the most common cause of cirrhosis in our country. Cirrhosis due to HCV mainly affects the adults of late middle age. Since the definitive treatment for cirrhosis is liver transplantation which is costly and is not exclusively available in our country. Therefore the best strategy is prevention of HCV infection by creating awareness in general public regarding the spread of this lethal virus.

\section{CopyrightC 01 Apr, 2010.}

\section{REFERENCES}

1. Schiff L. Diseases of the liver. $4^{\text {th }}$ ed. Philadelphia: JB Lippincot.1975.

2. Arif S, Khan AS, Khan AF. Changes in fibrinogen levels in liver cirrhosis. J Ayub Med Coll Abbottabad 2002; 14:
$19-21$.

3. Iqbal S,Rukunuddin. Liver cirrhosis in North West Frontier Province of Pakistan. J Coll Physician Surg Pak 2002;12: 289-91.

4. Detre KM, Belle SH, Lomabardero M. Liver transplantation for chronic viral hepatitis. Viral Hepat Rev 1997; 2: 219-28.

5. Dibiseglie AM. Hepatitis $\mathbf{C}$ and Hepatocellular carcinoma. Hepatology 1997; 26: 25-105.

6. Shaikh MA, Shaikh WM, Solangi GA, Abro H. Frequency and transmission mode of Hepatitis $C$ virus in Northern Sindh. J Coll Physician Surg Pak 2003; 13: 6913.

7. Khan TS, Rizvi F, Rashid A. Hepatitis C Virus seropositivity among chronic liver disease patients in Hazara, Pakistan. J Ayub Med CollAbbotabad 2003; 15 : 53-5.

8. Zuckerman AJ. The elusive Hepatitis C Virus. A cause of parentak non a non B hepatitis. Br Med J 1989; 299: 8712.

9. Shah NH, Shabbeir G. A review of published literature on hepatitis $B$ and $C$ virus in Pakistan. $J$ Coll Physician Surg Pak 2002. 12: 368-71.

10. Iqbal R. Screening of hepatitis $B$ and $C$ virus in chronic liver disease-a hospital based study. Pak J Med Sci 2003; 11:124-8.

11. Sherman M. Management of viral hepatitis: clinical and public health perspective- a consensus statement. Can J Gastroenterol 1997; 11: 407-16.

12. Bilal SN, Akhter S, Baber M. Spectrum of HCV positive cases in a gynae unit. J Postgrad Med Inst 2002; 16: 6871.

13. Jaferi SMW. Hepatitis C virus- the Pakistani perspective. J Coll Physician Surg Pak 2003; 13: 431-2.

14. Gul A, lqbal F. Prevalence of Hepatitis C Virus in patients on maintenance hemodialysis. J Coll Physician Surg Pak 2003; 13:431-2.

15. Dienstag JL, Isselbacher JK. Chronic hepatitis, in: Braunwald E, Fausi AS, Kasper DL, Hauser SL, Longo DL, Jameson JL, eds. Harrison's Principles of Internal 
Medicine. $15^{\text {th }}$ ed. San Francisco: McGraw Hill, 2001: $1742-52$.

16. Fattovich G. Morbidity and mortality in compensated cirrhosis type C: a retrospective follow up study of 384 patients. Gastroenterology 1997; 112: 63.

17. Steedmann A, Sarbah MD, Zobair M. Hepatitis C: an update on the silent epidemic. J Clin Gastroenterol 2000; 30: 1225-43.

18. Nadeem MA, WaseemT, Sheikh AM, Grumman N, Irfan K, Hasnain SS. Hepatitis $C$ virus: an alarming increasing cause of liver cirrhosis in Pakistan. Pak J Gastroenterol 2002; 16:3-8.

19. Khurram M, Khaar HTB, Javed S, Hasan Z, Arshad M,Goraya F, Rizwan A. Upper GI endoscopic evaluation of 299 patients with clinically compensated cirhosis. Pak J Gastroenterol 2003; 17: 12-6.

20. Umar M, Kanawl S, Chohan AR, Chohan S, Baqai HA, Khaar HTB, Ahmed S, Shah SF, Rathore AS, Hanif M. Pattern of esophageal varices and portal gastropathy in HCV related cirrhosis. Pak J Gastroentrol 2003; 17: 203.
21. Chohan AL, Shah SF, UmerM, Khaar HTB, Mehmood Z, NasirA, Ahmed S, Ajmal M, Riaz V, Akrm A. AST IALT ratio : a diagnostic tool to diagnose cirrhosis in patients with chronic hepatitis C infection. Pak J Gastroenterol 2003; 17: 17-9.

22. Faroogi JI, Khan PM. Viral etiology of liver cirrhosis patients in Swat. Pak J Gastroenterol 2002; 16: 39-42.

23. Khokhar N, Niazi SA, Chronic liver disease related mortality pattern I northern Pakistan. J Coll Physician Surg Pak 2003; 13: 495-7.

24. Khan AA, Rehman K, Haider Z, Shafqat F. Seromarkers of hepatitis $B$ and hepatitis $C$ in patients with cirrhosis. J Coll Physician Surg Pak 2002; 12: 105-7.

25. Sultana N, Bari A, Qazalbash AA. Prevalence of anti HCV antibodies in patients with liver disease and normal population. Pak J Med Res 1999; 38: 106-11.

26. Fattovich G, Pantalena M, Zagni I, Reaidi G. Schalm SW, Christrensin E, et al. Effects of HBV and HCV infection on the natural history of compensated cirrhosis: a cohort study of 297 patients. Am J Gastroenterol 2002; 97:2886-95.

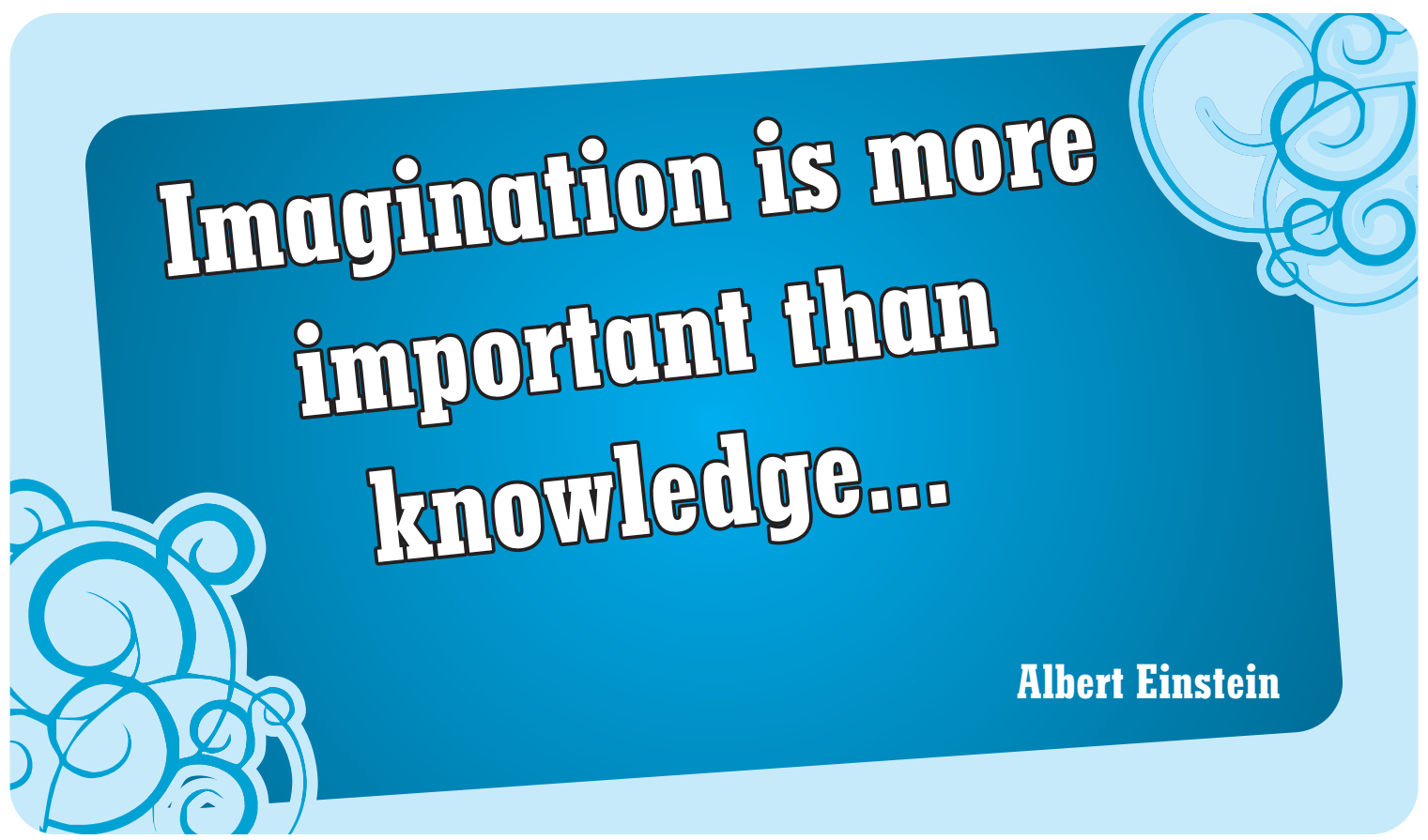

